\title{
Correction to: Biodeterioration in art: a case study of Munch's paintings
}

\author{
Cátia Salvador $^{1, a}{ }_{\mathbb{D}}$, Irina Crina Anca Sandu ${ }^{2}$, Erika Sandbakken ${ }^{2}$, António Candeias ${ }^{1,3,4}$ ED $_{\text {, A. Teresa Caldeira }}^{1,3,4}$
}

${ }_{1}^{1}$ HERCULES Laboratory, Institute for Advanced Studies and Research, University of Évora, Largo Marquês de Marialva 8, 7000-809 Évora, Portugal

2 Conservation Department, Munch Museum, Tøyengata 53, Oslo, Norway

${ }^{3}$ Chemistry and Biochemistry Department, Scholl of Sciences and Technology, University of Évora, Rua Romão Ramalho 8 59, 7000-671 Évora, Portugal

${ }^{4}$ City U Macau Chair in Sustainable Heritage, Institute for Advanced Studies and Research, University of Évora, Largo Marquês de Marialva 8, 7000809 Évora, Portugal

(C) The Author(s), under exclusive licence to Società Italiana di Fisica and Springer-Verlag GmbH Germany, part of Springer Nature 2022

\section{Correction to: The European Physical Journal Plus (2021) 137:1-19 https://doi.org/10.1140/epjp/s13360-021-02187-0}

In this article, the author name Irina Crina Anca Sandu was incorrectly written as Irina Sandu.

The original article can be found online at https://doi.org/10.1140/epjp/s13360-021-02187-0.

\footnotetext{
a e-mail: cscs@uevora.pt (corresponding author)
} 